\title{
Application of Decision-Making Methods in Smart City Projects: A Systematic Literature Review
}

\author{
Giang Tran Thi Hoang ${ }^{1,2}$, Laurent Dupont ${ }^{1, *} \mathbb{C}$ and Mauricio Camargo ${ }^{1}$ (i) \\ 1 Équipe de Recherche sur les Processus Innovatifs, ERPI, Université de Lorraine, 54000 Nancy, France \\ 2 Faculty of Project Management, The University of Danang-University of Science and Technology, \\ Danang City 550000, Vietnam \\ * Correspondence: 1.dupont@univ-lorraine.fr
}

Received: 15 July 2019; Accepted: 21 August 2019; Published: 5 September 2019

\begin{abstract}
In the current era, Smart City projects have to deal with big social, ecological, and technological challenges such as digitalization, pollution, democratic aspirations, more security, etc. The higher involvement of multi-stakeholders in the different phases of the projects is one strategy, enabling a variety of perspectives to be considered and thus to develop a shared vision of the city. Paradoxically, the dynamic and multiple natures of stakeholders appear to be a source of complication and uncertainty in the decision-making process. This study aims to provide a better understanding of this paradox and uses a systematic literature review methodology, as an original big data analysis, in order to investigate decision-making methods, enabling communication between multi-stakeholders, especially the involvement of citizens, into various phases of Smart City projects. Beginning with 606 papers, a bibliometric process led to the selection of 76 of these articles. Detailed analysis of these documents generated a general map for applying different decision-making methods at various levels of decision and implementation phases.
\end{abstract}

Keywords: decision-making; methods; Smart City; bibliometric approach

\section{Introduction}

Cities are places wherein different interrelated characteristics of ecosystems cohabit and interact. As a system, cities have become increasingly complex due to unpredictable behaviors and the existence of non-linear relationships between their constitutive elements [1,2]. A sustainable process of urban transformation into a Smart City requires co-operations supported by Information Communication and Technology (ICT) infrastructures, but also the integration of other dimensions, such as sustainable development, green growth, and collaborations between multi-stakeholders on multiple levels [3]. Therefore, making decisions in the context of Smart Cities has become more complex than ever due to the wealth of information available, both qualitative and quantitative data coming from various sources, and the involvement of multi-stakeholders with often conflicting objectives and dynamic interactions at different phases of these projects. For this reason, it is important to study how urban projects became smarter through the wise management of natural resources and participatory governance with the involvement of multi-stakeholders such as citizens, users, engineers, researchers, elected representatives, etc. A large number of new ideas, techniques, and approaches have contributed to the field of research on decision-making in smart cities in recent years [4]. However, no general consensus yet exists on the optimal decision-making tool to use to support stakeholders at each level of decision-making, each stage of the project, and for each particular context.

Therefore, this paper aims to propose a systematic literature review of formalization tools for decision-making processes in collaborative smart city projects. To achieve this, 606 research articles published between 2005 and 2018 extracted from the Scopus ${ }^{\circledR}$ database were found and analyzed 
using a co-occurrence approach conducted with VOSviewer software. Thus, among this huge panel of scientific data, 76 significant references in terms of different decision-making methods were selected and then sorted according to the main characteristics of smart cities. Based on the categorical reviews in [5], decision-making methods were classified into four groups: multi-criteria decision-making (MCDM), mathematical programming (MP), artificial intelligence (AI), and integrated methods (IM). In this study, decision making methods were reviewed according to three aspects: (1) levels of decision-making, (2) phases of implementation, and (3) involvement of and negotiation between stakeholders. This review, supported by algorithms and database analysis, is necessary to increase the understanding of how decision-making methods are applied in smart city projects and, subsequently, to inform researchers how to choose the correct approaches in order to formulate and optimize the decision-making process.

\section{General Background}

\subsection{Smart Cities and Their Main Characteristics}

Cities are increasingly growing to become larger and more complex than ever. As a consequence, dealing with issues such as mobility, pollution, health risks, or new infrastructures, among others, can often no longer be treated exclusively by city authorities, merely with traditional top-down approaches, and so increasingly the city authorities choose to integrate the active participation of end users and other stakeholders. A Smart City is considered as a city seeking to address public issues via ICT-based solutions on the basis of a multi-stakeholder and municipally-based partnership [6]. Several project management and urban studies have investigated citizens as users and stakeholders of urban projects [7].

In another definition, the Smart City is considered to be a well performing and forward-looking city using the smart combination of six main characteristics: economy, people, governance, mobility, environment, and living [8]. These characteristics form the framework for assessing the performance of smart cities. Smart economy focuses on economic factors related to competitiveness and integration of firms such as innovation, entrepreneurship, symbols, efficiency, and flexibility of the labor market in both the national and international marketplace. The term smart people represents quality of life, level of education of citizens, and the ways in which they integrate and interact with others in an open life. Smart mobility refers to the use of available and accessible ICTs in modes of transportation and transport systems. Attractive natural conditions (e.g., climate, green space) as well as managing and protecting natural resources are the important aspects of the smart environment. Smart living focuses on other aspects of life in a city, such as culture, health, security, housing, tourism, etc. Finally, smart governance comprises aspects of political participation and services for citizens that facilitate the involvement of citizens in transparent processes promoting collaboration, data exchange, service integration, and communication. Some studies identify smart governance as the core in determining the success or failure of projects [9] or one of the driving forces in the Smart City framework that fosters the innovation and sustainable economic development [10].

The role of governance in a Smart City not only focuses on adopting new technologies but also on improving the transparency in sharing data and decision-making. The contribution of stakeholders, especially citizens of the smart city is based on their ideas for the future development policy. Therefore, smart governance is also considered as participatory governance or citizen-centric governance. In a Smart City, Information Communication and Technology (ICT) plays an important role for policy makers to collect data and govern the city in a better way with well-informed decisions and adequate policies [11]. This leads to the data-led governance in a Smart City that is affected by the internet of things (IoT), sensors, and big data. Smart City governance is inherently complex, with the multi-context and multi-level ecosystem of various stakeholders who are often driven by conflicting interests [12]. These dynamic and multiple natures appear to be a key source of complexity and uncertainty in decision-making processes [5]. 
This generates a need for effective decision-making tools for dealing with complex and sometimes conflicting issues in urban development projects [3]. In the following paragraphs, the types of decision-making methods as well as the levels of decision-making and the phase of implementation of the project considered in the present study are presented and described.

\subsection{Categories of Decision-Making Methods}

Based on categorical reviews proposed in [5], decision-making methods are classified into: Multi-criteria decision-making, mathematical programming, artificial intelligence, and integrated methods.

Multi-criteria decision-making (MCDM) is a multi-step process consisting of a set of methods to structure and formalize decision-making processes. These allow decision-makers to find the best compromise among a set of possibilities by assessing these possibilities simultaneously according to multiple dimensions (criteria). However, MCDM is considered a steady-state method, providing snapshots of hotspots based on historical data. This method therefore does not provide projections or future trends, nor does it take into account the interactions of different metrics, outputs, and parameters over time [13].

Mathematical programming (MP) methods optimize objectives by considering the constraints and various issues within which stakeholders must make an effective decision. Several optimization methods, such as goal programming, linear programming, stochastic programming, and data envelopment analysis have been applied in this area. A significant problem with using mathematical programming methods, however, is that most MP methods are too complex for practical use by non-expert stakeholders [14].

In order to overcome limitations in MP models relating to dynamic complexity and nonlinear properties, great advances have been made in computer techniques, particularly the use of complex analysis and artificial intelligence (AI) methods such as cellular automata, multi-agent systems, swarm intelligence, genetic algorithms, simulated annealing, Bayesian networks, and reasoning systems. These methods are based on computer-aided systems that perceive the environment and take actions as a human would [15]. These methods are widely accepted to tackle complex and dynamic problems in urban studies by using Information and Communications Technology-based solutions and highly advanced computer programs. There is also the integrated methods (IM) methodology which seeks to combine the advantages of the afore-described methods.

\subsection{Level of Decision-Making}

In the context of the smart city and urban projects, decisions are made on three main levels: strategic, tactical and operational $[16,17]$. This multi-level governance is used as an analytical framework to analyze how smart city authorities deal with complex issues, and how stakeholders are connected [17].

The strategic level of decision-making is the basis for tactical and operational decisions [18]. The strategic level includes processes and activities for setting long-term goals, policy development, visions, or values for the overall development of the city as a whole.

The tactical level considers medium-term mid-level decisions to achieve the results specified at the strategic level. This level refers to the development of concrete green-space related agendas and all actors who regularly deal with programs, funding, and establishment of networks and partnerships. These actors include planners, universities, etc.

Finally, the operational level corresponds to experiments and actions with a short-term vision, which involve the implementation of goals and execution of concrete projects [19]. Operational decisions are mostly used to give operational solutions or to assess results obtained by low-level managers in smart cities [20].

\subsection{Phases of Urban Process: From Concept to Model, Experimentation, and Assessment}

The term process in various concepts of smart city government is defined by the ways in which stakeholders interact to exchange information, communicate, collaborate, or implement decisions [12]. 
In the work of [21], implementation is described as the process of putting a decision or plan into execution. The names of phases of implementing urban processes differ across nations, cultures, and scopes of studies. For example, in the French system, an urban process includes six stages, beginning with the emergence of a problem, formulation of the problem, technical formulation, formulation of a solution, implementation of the solution, and finally, appropriation of the solution [22,23]. Meanwhile, three stages, concept, development and implementation, are used to assess urban ecosystem services [24]. As the stakeholders involved have different information and knowledge of the problems, their complex decisions should be exposed to negotiation in various phases of the process.

In this study, the authors consider phases of implementing solutions as a process of four phases: conception, creating a model, experimenting to test the model, and assessing the model solution. This generic process is defined as a maturation and development process for real-life processes toward final forms that are marketable and can be completely adopted by users [3]. In an industrial setting, concepts are the first collaborative products at the early stages of design. Concepts enable an improved formulation of the meaning, planning, and program of a project [25]. Based on concepts, models are executed as a representation of a system using general rules. In the scientific method, an experiment is an empirical procedure which arbitrates models [26]. Researchers use experimentation to test existing models from trial to real-life conditions in order to support or disprove them. Finally, it is important to gain an assessment of solutions from multi- stakeholders, including citizens or users, so as to embrace as many points of view as possible and make a robust decision based on a broad range of knowledge of the situation.

\section{Materials and Methods}

In this study, the approach was the systematic literature selection process using different filters to narrow the number of scientific publications relating to decision-making in Smart Cities. Figure 1 shows a flow diagram as a process including four filters with different search strategies and exclusion criteria. The large number of articles collected after the first filter form the data for a qualitative data analysis carried out by VOSviewer ${ }^{\circledR}$ software. VOSviewer is freely available software at www.vosviewer.com. This software tool provides bibliometric mapping based on a network of keywords. It implements the mapping technique, and co-occurrence data analysis following a similarity matrix [27]. The VOS (visualization of similarities) mapping provides a high quality of visual representation to explore the maps in detail by offering zooming and scrolling options. Finally, publications selected after the fourth filter were retained and used for a quantitative review.

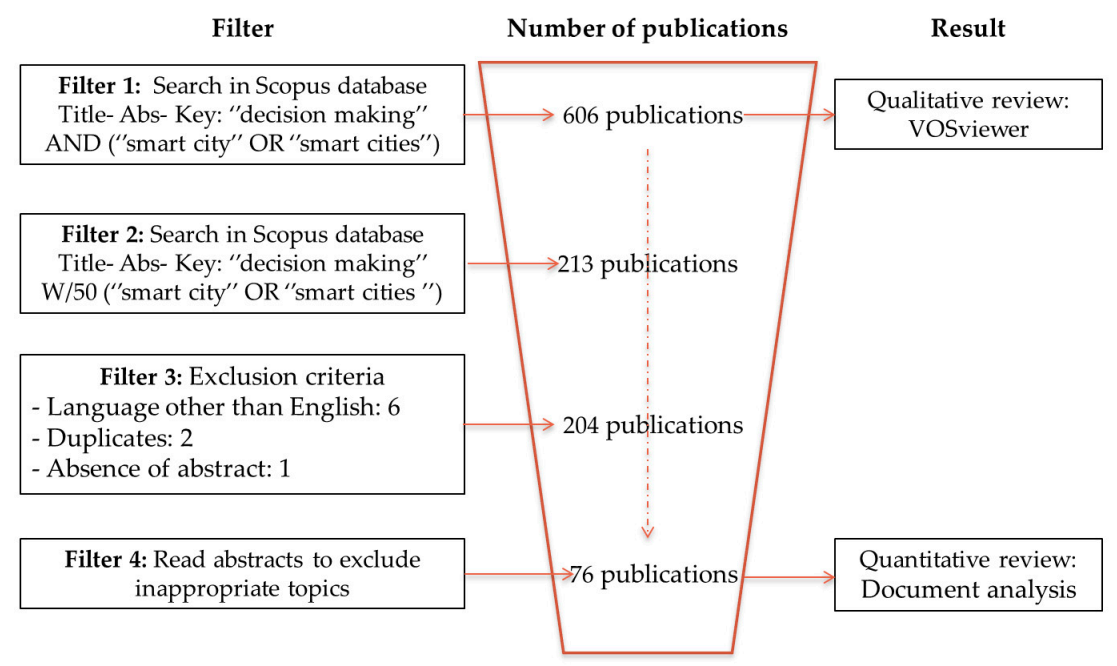

Figure 1. Flow diagram of the literature selection process. 


\subsection{First Search Strategy: The First Filter}

This step consisted of defining the first filter as a search equation, which was composed of keywords, period of time, database, and type of documents to be analyzed (Table 1). The keyword field was divided into two complementary parts. The first concerned "decision-making", and the second "smart city". These keywords were defined according to a preliminary literature review [16], whereas the period of time was selected from the year 2018 backwards. The focus was only on articles and conference papers; therefore, unpublished articles, working papers, and magazine articles were excluded during the data refinement process.

Table 1. The first search strategy.

\begin{tabular}{cc}
\hline Field & Option Introduced \\
\hline Keywords & "decision making" AND ("smart city" OR "smart cities") \\
\hline Search in & Title, abstract, keywords \\
\hline Period explored & to 2018 \\
\hline Type of documents & Articles and conference papers \\
\hline Database & Scopus ${ }^{\circledR}$ \\
\hline
\end{tabular}

After applying the first search strategy, 606 initial scientific publications were found in the Scopus ${ }^{\circledR}$ database. The whole database of 606 papers according to their title, keyword statistics, citation counts, author names, and affiliations were collected and exported from the Scopus website into a CSV data file. The data were then uploaded to the VOSviewer software. This large amount of data constituted the input for bibliometric mapping and conducting a network of keywords and their relatedness by means of co-occurrence analysis. This result is discussed later in Section 4.1.

\subsection{Second Search Strategy: The Second Filter}

In this search equation, the proximity operator "w/50" was used between two sets of keywords: "decision-making" and "smart city". This is a search tip provided by the Scopus website to make sure all search terms appear in the title or in the same paragraph. By using this tip, the number of selected publications was narrowed down and the topic of these studies was more relevant to the present objectives. In this step, the period of time searched, database, and type of documents were similar to the first search step. After applying this search strategy, 213 potential publications were found on the Scopus database.

\subsection{Third Filter}

The number of publications was subsequently selected or excluded using support tools available on the Scopus website. The three main exclusion criteria were: language other than English, duplicates, and absence of abstract. The 204 remaining scientific publications were used to constitute the initial data statistics.

\subsection{Fourth Filter}

There were several works unrelated to the Smart City topic in 204 scientific publications from the previous filter. Several reviews and theoretical studies did not perform a concrete method to make a decision or lacked practical contribution in projects or case studies. In order to choose the most relevant papers, a filter was performed based on reading and analyzing the abstracts of these 204 selected articles. From this, articles using different methods to formulate decision-making processes in concrete smart city projects were retained and listed herein. These 76 selected papers were carefully reviewed and selected strictly according to the category of decision-making methods formulated above, levels of 
decision-making, and phases of implementation of smart city projects. The result of this quantitative analysis is discussed in Section 4.2.

\section{Results}

\subsection{Qualitative Review: Data Statistics Generated by VOSviewer}

The 606 publications selected from the first search strategy were transferred as bibliographical data to the VOSviewer software. These bibliographical data were used to develop a network of keywords by co-occurrence links. The whole network of keywords and their links is mapped out in Figure 2. In this network, the circles are a representation of keywords and the diameter of circles represents for the frequency of occurrence of each keyword. The distance between two keywords indicates their relatedness in terms of co-occurrence links. These co-occurrence links were determined based on the number of documents in which keywords occur together. So, the closer two keywords are located to each other, the stronger their relatedness.

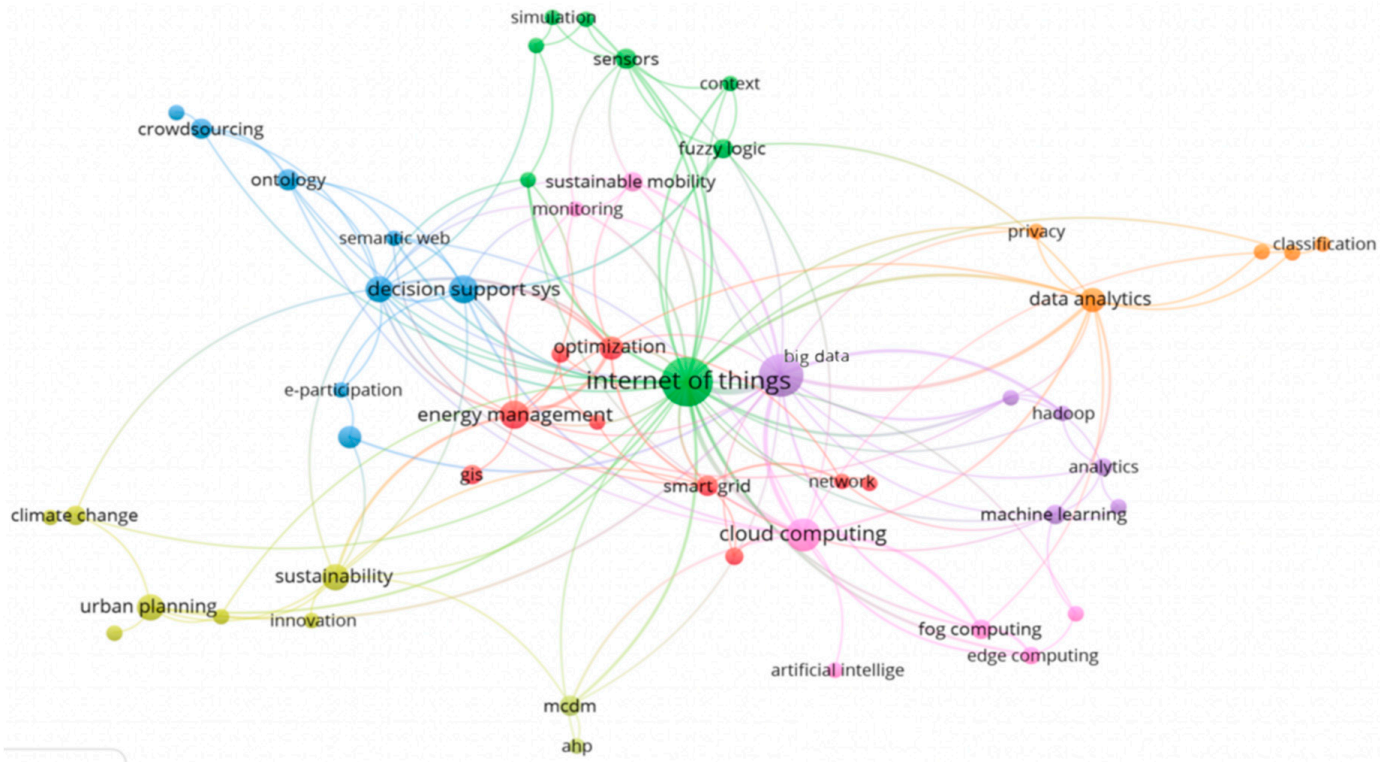

Figure 2. A network analysis of 606 publications by the VOSviewer software. $\mathrm{mcdm}=$ multi-criteria decision-making, ahp = Analytic Hierarchy Process.

In the network, a collection of keywords having a strong relationship creates clusters, each presented with different colors. Using all the keywords in one cluster for the search equation in the Scopus database, a list of papers was found that represented the research trend of each cluster. The seven main clusters of networks identified by VOSviewer are described in Table 2, which includes the color, components of clusters, some example publications, and current research mentioned in each cluster.

Table 2. Cluster analysis. ICT = Information Communication and Technology; IOT = internet of things; GIS = geographic information system .

\begin{tabular}{lllll}
\hline Cluster & Main Keywords & Other Keywords & $\begin{array}{l}\text { Example } \\
\text { Reference }\end{array}$ & Research Trend \\
\hline 1 (green) & Internet of things & $\begin{array}{l}\text { fuzzy logic, Smart home, sensors, } \\
\text { waste management, context, } \\
\text { carbon footprint, simulation }\end{array}$ & {$[28,29]$} & $\begin{array}{l}\text { IoT- based application for } \\
\text { smart city }\end{array}$ \\
\hline 2 (blue) & $\begin{array}{l}\text { Decision support } \\
\text { system, ICT }\end{array}$ & $\begin{array}{l}\text { e-participation, smart governance, } \\
\text { crowdsourcing, emergency } \\
\text { response, ontology, semantic web }\end{array}$ & {$[30,31]$} & $\begin{array}{l}\text { Decision support system } \\
\text { based on ICT for smart } \\
\text { governance }\end{array}$ \\
\hline
\end{tabular}


Table 2. Cont.

\begin{tabular}{lllll}
\hline Cluster & Main Keywords & Other Keywords & $\begin{array}{l}\text { Example } \\
\text { Reference }\end{array}$ & Research Trend \\
\hline 3 (purple) & Big data & $\begin{array}{l}\text { deep learning, machine learning, } \\
\text { healthcare, intelligent } \\
\text { transportation system }\end{array}$ & {$[32,33]$} & $\begin{array}{l}\text { The application of big data } \\
\text { analysis and data mining } \\
\text { algorithms in smart cities }\end{array}$ \\
\hline 4 (red) & Optimization & $\begin{array}{l}\text { smart grid, energy management, } \\
\text { GIS, network, security, } \\
\text { visualization, game theory, } \\
\text { demand response }\end{array}$ & {$[34,35]$} & $\begin{array}{l}\text { Optimization tools for } \\
\text { networks in smart cities }\end{array}$ \\
\hline 5 (yellow) & Sustainability & $\begin{array}{l}\text { infrastructure, innovation, social } \\
\text { network, urban planning, earth } \\
\text { observation, climate change, } \\
\text { MCDM, AHP }\end{array}$ & {$[36,37]$} & $\begin{array}{l}\text { Assessment of sustainability } \\
\text { of smart cities }\end{array}$ \\
\hline 6 (pink) & Cloud computing & $\begin{array}{l}\text { artificial intelligence, edge } \\
\text { computing, fog computing }\end{array}$ & {$[38,39]$} & $\begin{array}{l}\text { Decision based on cloud } \\
\text { computing and artificial } \\
\text { intelligence methods }\end{array}$ \\
\hline 7 (orange) & Data analytics & $\begin{array}{l}\text { open data, wireless sensor } \\
\text { networks, privacy, classification }\end{array}$ & {$[40,41]$} & $\begin{array}{l}\text { Data analytics, a paradigm } \\
\text { and solution for } \\
\text { decision-making }\end{array}$ \\
\hline
\end{tabular}

After exploring the cluster network, it is interesting to continue to discover the distribution and evolution over time of keywords in the network. Using the overlay and density visualization of VOSviewer, the same network could display the total occurrence and time period of research of each keyword. In Figure 3, colors are defined by the average publication per year of each keyword, with yellow representing the most recent and dark blue representing the oldest. It can be observed that the present research issue is a recent topic with an average time of publication ranging between 2016 and 2018. Clusters on the left emerged mainly in 2016, while the internet of things-based solutions and application of decision-making methods (such as MCDM, computing, or artificial intelligence) are now beginning to attract interest among academic communities. Figure 4 also shows the low density of focus on decision-making methods compared to other topics (Red circles). Therefore, this leads to a demand of studies focused more on application of decision-making methods in order to formulate the problems of smart city projects.

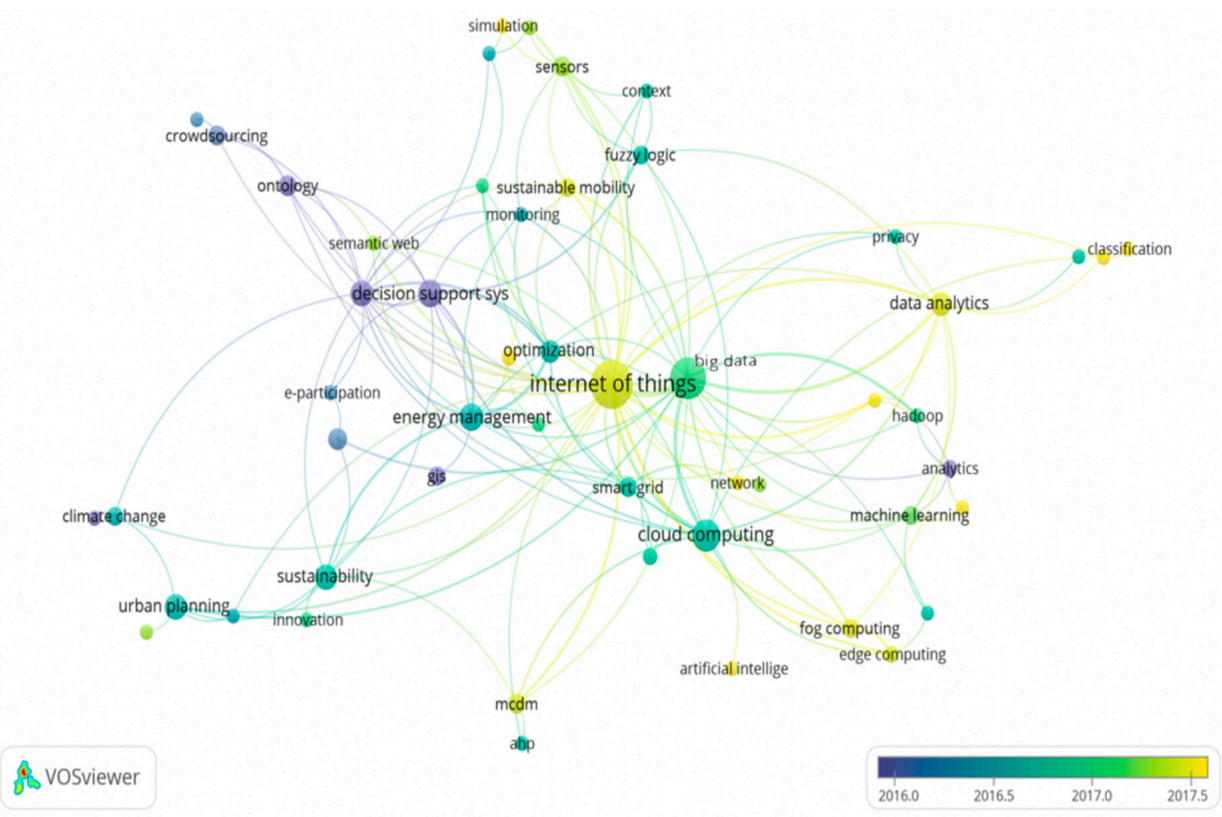

Figure 3. The evolution over time of keywords. 


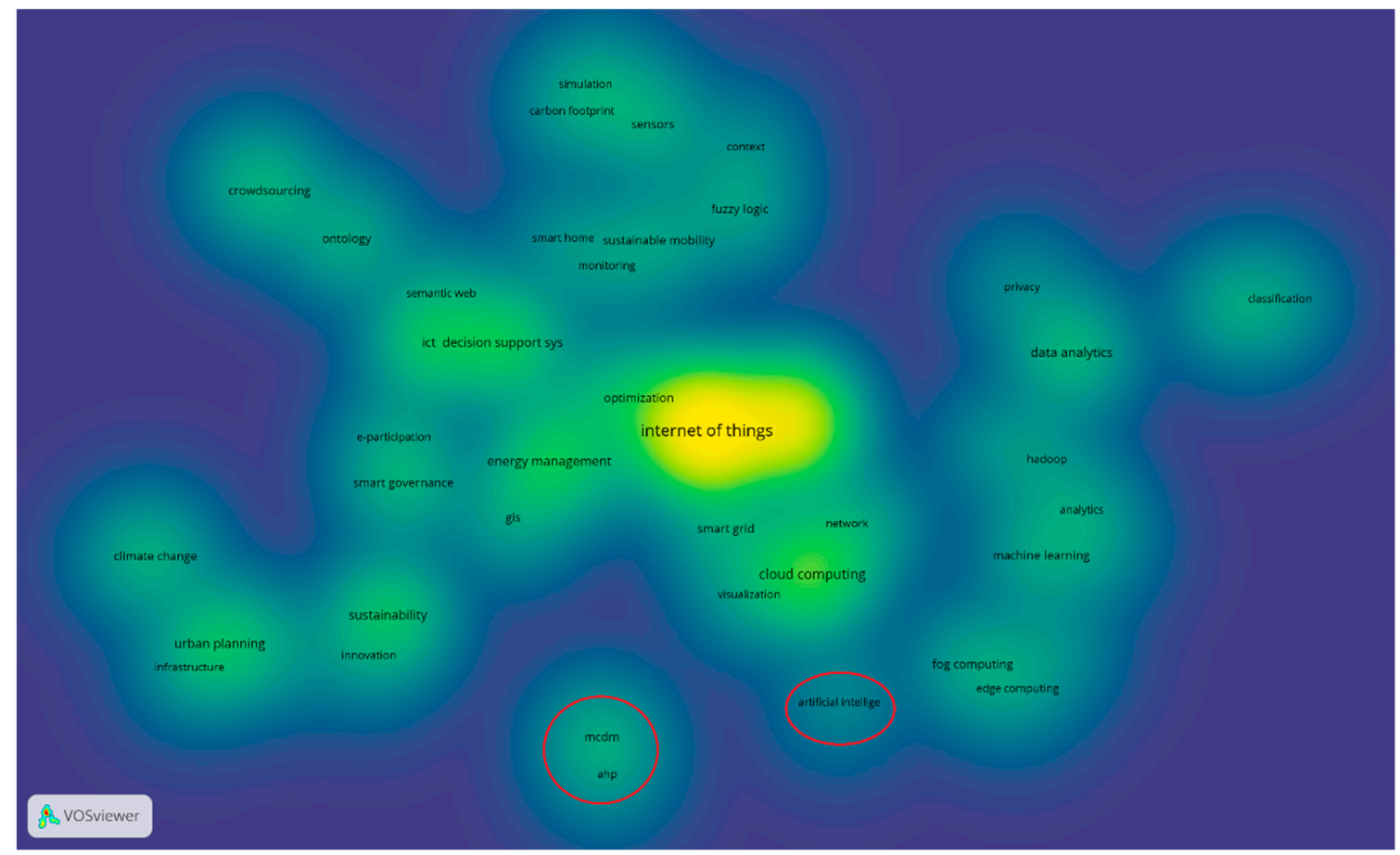

Figure 4. A visual diagram of density distribution of keywords.

\subsection{Quantitative Review: Document Analysis}

A methodological analysis was applied to sort the selected articles according to Filter 4 of the literature selection process. Appendix A provides detailed information of the 76 papers retained. This provides an overall summary of the four groups of decision-making methods discussed in the set of selected journal articles. The level of decision-making (strategic, tactical, or operational level) was also identified. Then, the methods used to formulate the decision-making process for different phases of Smart City projects (see Section 2.4) were analyzed.

\section{Discussion}

\subsection{Trend of Publications}

Figure 5 shows a notable increase in published studies regarding decision-making processes in Smart City projects over the past 10 years. The evolution of the 76 selected studies over the years is represented in column data. In order to compare this trend, the red line represents the total 213 articles collected from the Scopus database after the second filter of the selection process was applied and the yellow line represents normalized data. The normalization process starts from the actual number of publications per year that were published at https://dblp.uni-trier.de/statistics/publicationsperyear. After computing the increase rate for each year, we normalized the data from the Scopus database.

In general, the evolution begins with a handful of papers per year in the period of 2008 to 2011, then rises dramatically from 2012 and peaks in 2018. Around half of these studies address individual problems, while the remaining works were related to collaborative decisions. The detail analysis on group decision-making is presented in the next section. 


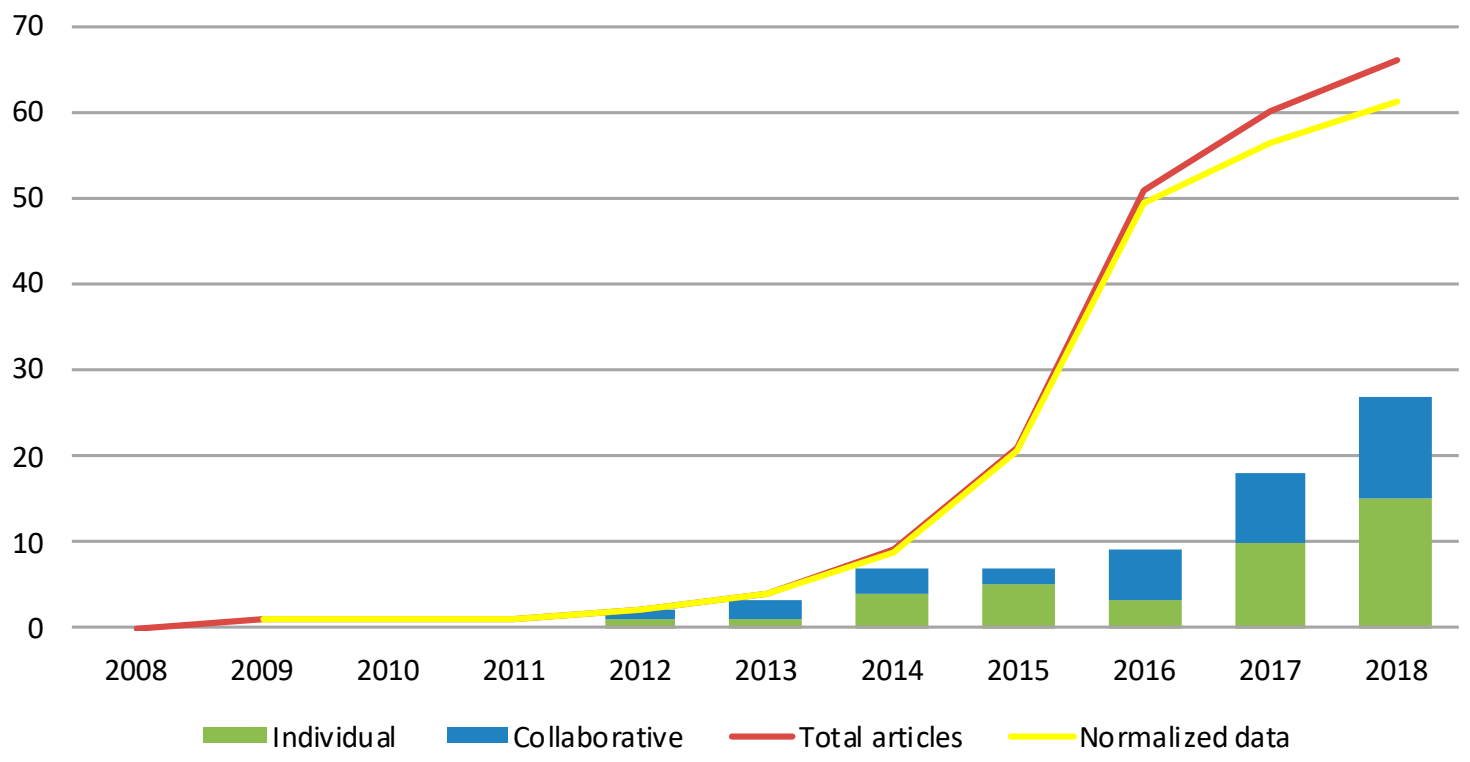

Figure 5. Distribution of publications between 2008 and 2018 (source: Scopus database).

Figure 6a shows the percentage of publications according to their scope, based on the set of main characteristics of smart cities. It highlights the dominance of studies pertaining to smart mobility and smart environment, which amounted to $38 \%$ and $27 \%$ of the publications, respectively. As mentioned in the literature, smart government plays an important role in smart city projects [9], however, only $8 \%$ of the articles focus on this topic. To close this gap, it is necessary to increasingly pay attention to creating smart governance models in order to improve multi-stakeholder participation in decision-making processes.

a)

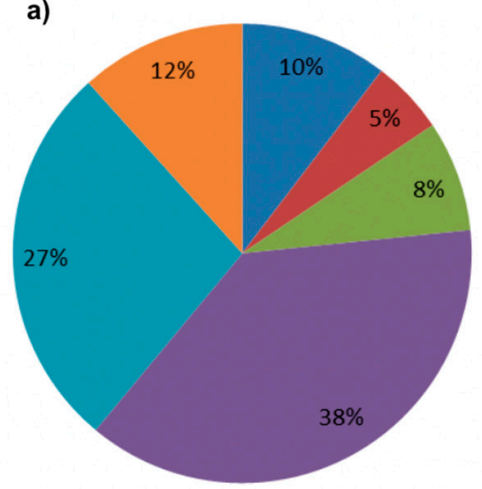

- smart economy

asmart people

In smart governance

asmart mobility

= smart environment

Insmart living b)

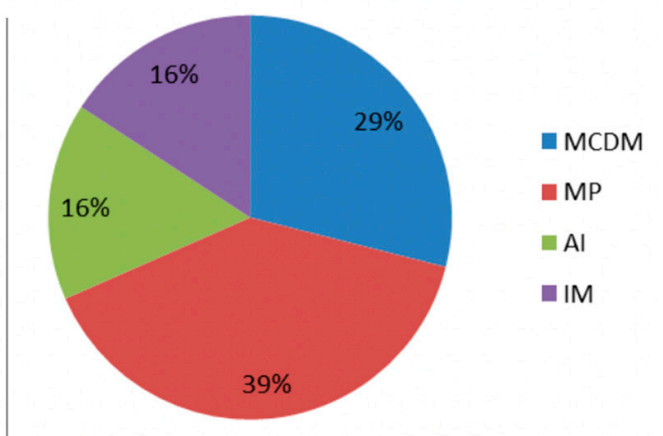

Figure 6. Distribution of 76 publications according to main characteristics (a), and decision-making methods (b) used in Smart City projects between 2008 and 2018. MP = mathematical programming; AI $=$ artificial intelligence; $\mathrm{IM}=$ integrated methods.

Figure 6b illustrates how, between 2008 and 2018, a considerable number of articles used MCDM and MP for Smart city projects. On the other hand, applying AI methods in urban decisions was not yet a popular trend in this period, with only 17 related articles. AI methods are usually combined with ICT-based tools to quickly analyze operational data and improve urban decisions [42,43]. In terms of AI methods, there are only four works in total applying agent-based methods, such as a the multi-agent system or agent-based model, to provide a decision support system in an automatic and robust way $[44,45]$. In addition to this, it can be observed in the review that the majority of studies mentioning IM methods demonstrate a combination between MCDM and other methods to formulate urban 
decision-making processes. This trend also attests to the overwhelming majority of MCDM methods used in this research area.

\subsection{Level of Decision-Making}

Figure 7 shows that MCDM is a popular method at a strategic level. MCDM methods are widely used in strategic planning to analyze and interpret the multiple interactions underpinning complex urban environments $[46,47]$ or to select the most suitable solution as a recommended strategy for public sectors [48,49].

Meanwhile, MP and AI are mostly applied to develop ontologies and tools supporting operational and tactical decision-making with concrete objectives. For example, MP methods are applied to create data aggregation and service production for smart city projects [50,51]. MP methods also contribute to assessing and optimizing energy efficiency $[52,53]$ or spatial data infrastructure projects $[54,55]$. Beyond this, AI methods provide the potential for solving high levels of complexity in the modeling process. For example, AI methods quickly analyze operational data to provide new insights and improve decision-making in the industrial system [42] or various social science theories of human behavior [44].

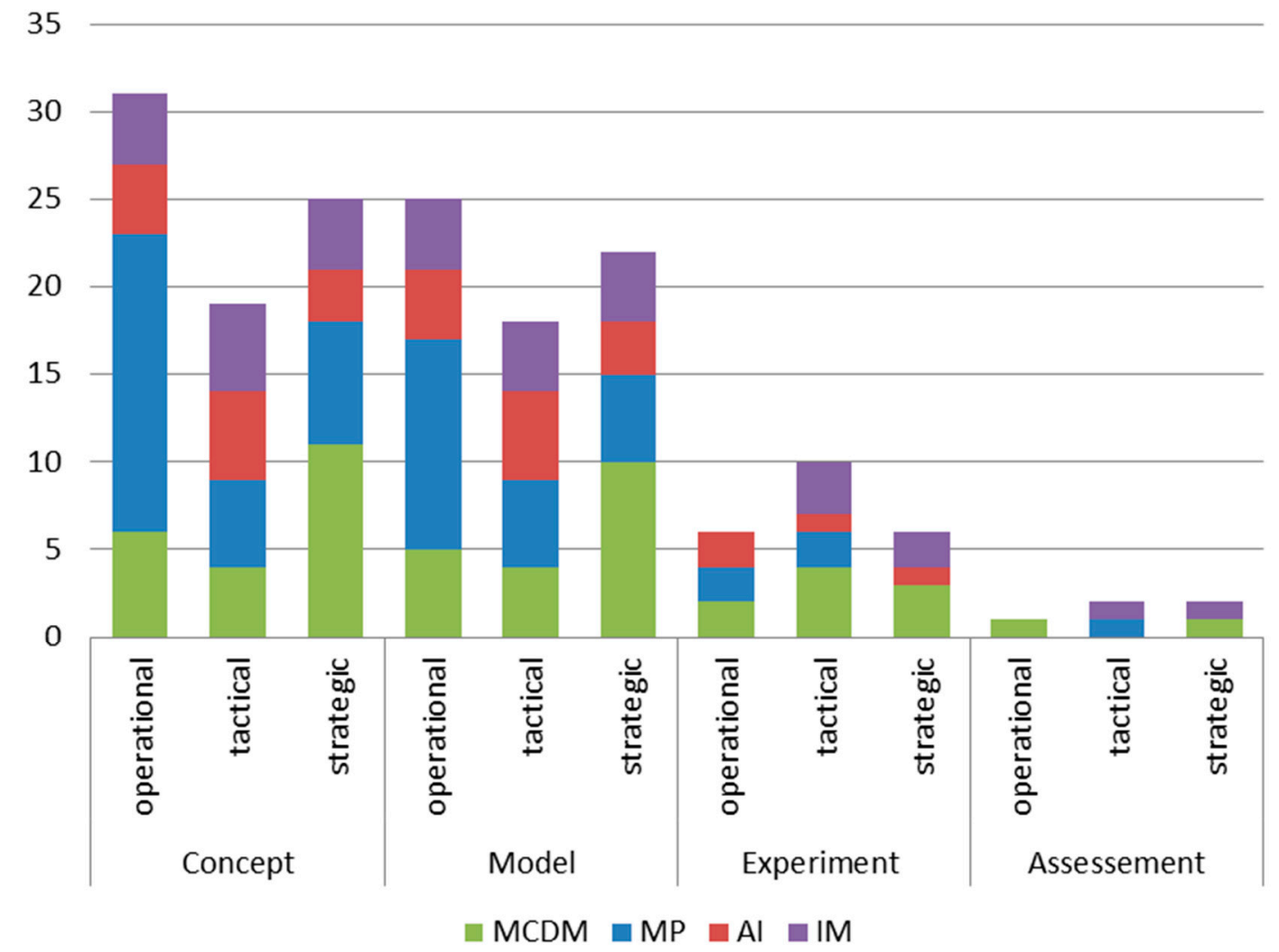

Figure 7. Distribution of 76 publications by level of decision-making and phases of implementation.

\subsection{Phase of Implementation: From Concept to Model, Experiment and Assessment}

Figure 7 also shows that MCDM and integrating MCDM with other methods are used in all phases of urban projects, from concept to experiment and finally, assessment of solutions of decision-making tools in real-life practices. This method is a holistic procedure for smart city projects on multiple levels, providing and using a multi-criteria perspective. Decision-making tools are provided to support the diagnosis, selection, and final assessment of measures and scenarios that enable the mass-market deployment of energy-efficient projects [56]. In another example, the multi-actor multi-criteria analysis methodology is fully explained to assess urban freight solutions in order to appraise their chance of 
success [48]. Case studies in these articles are considered as references for the large demonstration cases in smart cities.

Meanwhile, MP and AI are mostly applied to developing tools at the beginning phases of the implementation processes. Several levels of models from conceptual to scale are designed and executed within smart cities. However, there is a gap between modeling the decision-making processes and experimenting with and assessing such models. MP and AI methods are usually used as a representation of a system to create a model and prototype in a real-life context that enables the visualization of internal relationships within collaborative platforms [52,54].

Figure 7 also depicts the main publication journals related to the levels of decision-making and phases of Smart City projects between 2008 and 2018. As can be seen, most studies in this period developed a build concept and executed the model. Of the 76 studies examined in this review, only 16 studies were found to experiment with their decision-making tools in a real-life context. Of these 16 studies, six articles related to the assessment of decision-making tools made by multi-stakeholders or the author only. These results imply that decision-making tools are mainly executed at the beginning of the implementation process of urban projects. The involvement of multi-stakeholders in this assessment process is an extremely important aspect, as will be discussed in the next section. Moreover, from this review, some supplementary aspects can also be underlined.

\subsection{The Involvement of Citizens and Other Stakeholders in Group Decision-Making}

A large number of new ideas, techniques, and approaches have all contributed to emphasize the importance of involving stakeholders, in particular users and citizens, in the development of collaborative decision-making processes for smart city projects.

Even though around half of all the studies concerned group decision-making, most of the decision-making tools and toolkits were modeled and executed by experts or authors alone. Out of all the papers, only 19 (i.e., 28\%) explored the involvement of multi-stakeholders. In cases where stakeholders were involved, they were rarely given the opportunity to negotiate and reach a higher level of agreement. In some cases, they merely debated or negotiated in several rounds [30] instead of compromising to reach a consensus. Processes for reaching a consensus are not a new concept in social science. However, according to the present literature review, the term "consensus" is only cited in a few articles. The decision-making methods that support processes for reaching a consensus are usually MP or AI methods [31]. The reason for this is that programming and computer-aided systems are available to solve complex and dynamic problems in negotiation processes when people are in conflict and also for compromising to share decisions.

\section{Conclusions}

In many studies, urban and smart city projects have been considered within complex contexts and over long time scales that revealed multi-stakeholders and organizations with conflicting interests. Therefore, smart city planning and decision-making are not only data-driven multi-level scaling practices, but are also a collective learning procedure supported by advanced ICT-based technologies and visualizations of available data, constant processes, and local history and stories [57]. In order to increase the efficiency of discussions and negotiations, there is a need for situational-awareness tools and approaches enabling collaborative decision-making processes that deal with the complex nature of smart city projects.

In this study, a systematic literature review methodology with four filters was used to narrow the number of potential articles collected from the Scopus database. Starting from a huge database of 606 papers, collaborative decision-making methods in smart city projects was undertaken through the qualitative analysis of 76 selected research documents.

This literature study contributes a general mapping of different decision-making methods applied at the levels of decision-making and the phases of implementation. The main contributions of this study are the following: 
- Even though smart government with citizen participation is an important characteristic of a smart city, few articles focus on this issue.

- $\quad$ MCDM is a popular method at every level of decision-making and throughout all stages of smart city projects. Meanwhile, MP and AI are widely used for making operational and tactical decisions.

- $\quad$ Regarding the implementation process, several papers cover all phases, from concept to modelling and assessing decision-making tools. However, assessing solutions, the final phase, tends to lack efficient engagement of multi stakeholders, especially citizens.

- $\quad$ The involvement of multi-stakeholders is not considered in most phases of smart city projects. In cases where they are involved, there is a lack of decision-making tools supporting the negotiation between stakeholders.

- As evidenced in Figure 7, the research efforts in this field remain in conceptual ideas and models.

Hence, there is an opportunity for future work to focus on smart government supporting the involvement of stakeholders, especially citizens, in decision-making processes and on the best ways in which to negotiate to reach a consensus. A combination of the wide applicability of MCDM methods and the capacity of mathematical and computer-based methods to solve complex problems could potentially produce an effective methodology for optimizing complex and dynamic decision-making processes in smart city projects.

Author Contributions: Conceptualization, G.T.T.H., L.D., and M.C.; Formal analysis, G.T.T.H., L.D., and M.C.; Investigation, G.T.T.H.; Methodology, G.T.T.H., L.D., and M.C.; Project administration, M.C.; Supervision, L.D. and M.C.; Validation, L.D. and M.C.; Visualization, G.T.T.H.; Writing—original draft, G.T.T.H., L.D., and M.C.; Writing-review and editing, G.T.T.H., L.D., and M.C.

Funding: This research received no external funding.

Acknowledgments: The authors would like to acknowledge the support received from the institutions and people who made this project possible.

Conflicts of Interest: The authors declare no conflict of interest. The funding parties had no role in the design of the study; nor in the collection, analyses, or interpretation of data; the writing of the manuscript, nor in the decision to publish the results.

\section{Appendix A}

Table A1. Publications summary. (O-Operational; T-Tactical; S-Strategic; C-Concept; M-Model; Ex-Experiment; A-Assessment; MS-Multi-Stakeholder involvement; I-Individual; G-Group; en—environment; pe-people; li-living; eco-economic; mo—mobility; go-government; DEMATEL—Decision making trial and evaluation laboratory; MAUT-Multi-Attribute Utility Theory; ABM-Agent-based models; TOPSIS-Technique for Order of Preference by Similarity to Ideal Solution; ANP_Analytic Network Process; GP_goal programming; LP_linear programming; SP_stochastic programming; DEA—data envelopment analysis; MAS—-multi agent system; SI—swarm intelligent; GA—genetic algorithm; SA—simulated annealing; RS—reasoning system).

\begin{tabular}{|c|c|c|c|c|c|c|c|c|c|c|c|c|c|c|}
\hline \multirow{2}{*}{ No } & \multirow{2}{*}{ Ref } & \multirow{2}{*}{$\begin{array}{c}\text { Main } \\
\text { Characteristic }\end{array}$} & \multirow{2}{*}{$\begin{array}{l}\text { Group of } \\
\text { Method }\end{array}$} & \multirow{2}{*}{ Method } & \multicolumn{3}{|c|}{ Level of Decision } & \multicolumn{4}{|c|}{ Phase of Implementation } & \multirow{2}{*}{ MS } & \multicolumn{2}{|c|}{ Type } \\
\hline & & & & & $\mathrm{O}$ & $\mathrm{T}$ & $\mathrm{S}$ & $\mathrm{C}$ & $\mathbf{M}$ & Ex & A & & I & G \\
\hline 1 & {$[58]$} & li & MCDM & DEMATEL & & & $x$ & & & $x$ & & & & $\mathrm{x}$ \\
\hline 2 & [59] & go & $\mathrm{AI}$ & Bayesian & $x$ & & & & & $x$ & & & & $\mathrm{x}$ \\
\hline 3 & {$[50]$} & li & MP & LP & $x$ & & & & $x$ & & & & $x$ & \\
\hline 4 & {$[60]$} & mo & MP & $\begin{array}{l}\text { Machine } \\
\text { leaning }\end{array}$ & $\mathrm{x}$ & & & & $x$ & & & & $x$ & \\
\hline 5 & [61] & mo & MP & MP & & $x$ & & & & & $x$ & $x$ & & $\mathrm{x}$ \\
\hline 6 & [62] & li & IM & $\begin{array}{l}\text { MCDM } \\
\text { and AI }\end{array}$ & $x$ & & & & $x$ & & & & & \\
\hline 7 & {$[63]$} & go & MP & $\begin{array}{c}\text { Cognitive } \\
\text { maps }\end{array}$ & & & $\mathrm{x}$ & & & $x$ & & & $x$ & \\
\hline 8 & [46] & mo & IM & LP & & & $x$ & & & & $x$ & & $x$ & \\
\hline
\end{tabular}


Table A1. Cont.

\begin{tabular}{|c|c|c|c|c|c|c|c|c|c|c|c|c|c|c|}
\hline \multirow{2}{*}{ No } & \multirow{2}{*}{ Ref } & \multirow{2}{*}{$\begin{array}{c}\text { Main } \\
\text { Characteristic }\end{array}$} & \multirow{2}{*}{$\begin{array}{l}\text { Group of } \\
\text { Method }\end{array}$} & \multirow{2}{*}{ Method } & \multicolumn{3}{|c|}{ Level of Decision } & \multicolumn{4}{|c|}{ Phase of Implementation } & \multirow{2}{*}{ MS } & \multicolumn{2}{|c|}{ Type } \\
\hline & & & & & $\mathrm{O}$ & $T$ & $\mathrm{~S}$ & $\mathrm{C}$ & $\mathbf{M}$ & Ex & $\mathbf{A}$ & & I & G \\
\hline 9 & {$[42]$} & eco & AI & AI & $\mathrm{x}$ & & & & & $\mathrm{x}$ & & & $\mathrm{x}$ & \\
\hline 10 & {$[40]$} & en & MP & MP & $\mathrm{x}$ & & & & $\mathrm{x}$ & & & & $\mathrm{x}$ & \\
\hline 11 & {$[52]$} & mo & MP & DEA & $\mathrm{x}$ & & & & $\mathrm{x}$ & & & & $\mathrm{x}$ & \\
\hline 12 & {$[64]$} & mo & $\mathrm{IM}$ & $\begin{array}{l}\text { IM and } \\
\text { MCDM }\end{array}$ & & $x$ & & & & $\mathrm{x}$ & & & $\mathrm{x}$ & \\
\hline 13 & {$[47]$} & en & MCDM & MAUT & & & $x$ & & $\mathrm{x}$ & & & & $\mathrm{x}$ & \\
\hline 14 & {$[54]$} & mo & MP & MP & $x$ & & & $x$ & & & & & $x$ & \\
\hline 15 & [65] & li & MP & MP & $\mathrm{x}$ & & & & & $\mathrm{x}$ & & & $\mathrm{x}$ & \\
\hline 16 & {$[44]$} & en & $\mathrm{AI}$ & $\mathrm{ABM}$ & $\mathrm{x}$ & & & & $\mathrm{x}$ & & & & $\mathrm{x}$ & \\
\hline 17 & {$[66]$} & mo & MP & MP & $x$ & & & & & $x$ & & & $x$ & \\
\hline 18 & [67] & go & MCDM & MCDM & & & $x$ & & & $x$ & & & & $\mathrm{x}$ \\
\hline 19 & [68] & go & MCDM & TOPSIS & $x$ & & & $x$ & & & & & & $x$ \\
\hline 20 & [69] & li & AI & MAS & $x$ & & & & & $x$ & & & $x$ & \\
\hline 21 & [70] & li & MP & MP & & & $x$ & & & & $x$ & $x$ & & $x$ \\
\hline 22 & [71] & li & AI & $\begin{array}{l}\text { Stream } \\
\text { reason }\end{array}$ & $\mathrm{x}$ & & & & & $x$ & & & $x$ & \\
\hline 23 & [72] & en & MP & $\begin{array}{c}\text { Edge } \\
\text { computing }\end{array}$ & $x$ & & & & $x$ & & & & & $x$ \\
\hline 24 & [48] & mo & MCDM & MAUT & & & $x$ & & & & $x$ & $x$ & & $\mathrm{x}$ \\
\hline 25 & [73] & mo & AI & $\begin{array}{l}\text { Artificial } \\
\text { network }\end{array}$ & $x$ & & & & $x$ & & & & $x$ & \\
\hline 26 & [74] & li & MP & $\mathrm{MP}$ & $x$ & & & & $x$ & & & & $x$ & \\
\hline 27 & [75] & li & MCDM & $\begin{array}{l}\text { ANP and } \\
\text { DEMATEL }\end{array}$ & & & $x$ & & & $x$ & & & $x$ & \\
\hline 28 & [51] & li & MP & MP & $x$ & & & & $x$ & & & & & $\mathrm{x}$ \\
\hline 29 & [76] & mo & MCDM & MAUT & & $x$ & & & & $x$ & & & & $\mathrm{x}$ \\
\hline 30 & [77] & mo & AI & GA & $x$ & & & & $x$ & $x$ & & & $x$ & \\
\hline 31 & [78] & mo & $\mathrm{AI}$ & MAS & $x$ & & & & $x$ & & & & $x$ & \\
\hline 32 & [53] & mo & MP & MP & $x$ & & & & & $x$ & & & $x$ & \\
\hline 33 & [79] & li & MCDM & MAUT & & & $x$ & & $x$ & & & $x$ & & $\mathrm{x}$ \\
\hline 34 & [80] & mo & $\mathrm{AI}$ & AI & $x$ & & & $x$ & & & & & $x$ & \\
\hline 35 & [81] & mo & MP & MP & $x$ & & & & & $x$ & & & $x$ & \\
\hline 36 & [82] & en & MCDM & MCDM & $x$ & & & & $x$ & & & & & $\mathrm{x}$ \\
\hline 37 & [83] & mo & MCDM & MAUT & & $x$ & & & & $x$ & & & & $\mathrm{x}$ \\
\hline 38 & [84] & li & MCDM & MCDM & $x$ & & & & & $x$ & & & & $\mathrm{x}$ \\
\hline 39 & [85] & en & MP & $\begin{array}{c}\text { Game } \\
\text { theoretic }\end{array}$ & $\mathrm{x}$ & & & & $x$ & & & & $x$ & \\
\hline 40 & [86] & li & MP & Non-LP & $x$ & & & & $x$ & & & & $x$ & \\
\hline 41 & [87] & mo & MP & MP & $x$ & & & & $x$ & & & & $x$ & \\
\hline 42 & [88] & mo & MCDM & MAUT & $x$ & & & & & $x$ & & & & $\mathrm{x}$ \\
\hline 43 & [89] & en & MCDM & MCDM & & & $x$ & & & $x$ & & & & $x$ \\
\hline 44 & [90] & eco & MP & MP & . & $x$ & & & $x$ & & & & $x$ & \\
\hline 45 & [91] & en & MP & MP & $x$ & & & & & & $x$ & $x$ & & $x$ \\
\hline 46 & [92] & go & $\mathrm{AI}$ & $\mathrm{AI}$ & & & $x$ & $x$ & & & & & & $\mathrm{x}$ \\
\hline 47 & [31] & go & $\mathrm{AI}$ & AI & & & $x$ & & $x$ & & & $x$ & & $\mathrm{x}$ \\
\hline 48 & [36] & en & MCDM & MCDM & & & $x$ & & $x$ & & & & $x$ & \\
\hline 49 & [43] & en & $\mathrm{AI}$ & AI & & $x$ & & & $x$ & & & & & $\mathrm{x}$ \\
\hline 50 & [93] & mo & MP & LP & & & . & & & $x$ & & & $x$ & \\
\hline 51 & [94] & en & MCDM & AHP & & & $x$ & & & $x$ & & & & $\mathrm{x}$ \\
\hline 52 & [95] & go & MCDM & MAUT & & & $x$ & & $x$ & & & & & $x$ \\
\hline 53 & [96] & go & MCDM & MAUT & $x$ & & & & $x$ & & & & & $\mathrm{x}$ \\
\hline 54 & [97] & en & MP & MP & $x$ & & $x$ & & & $x$ & & & & $x$ \\
\hline
\end{tabular}


Table A1. Cont.

\begin{tabular}{|c|c|c|c|c|c|c|c|c|c|c|c|c|c|c|}
\hline \multirow{2}{*}{ No } & \multirow{2}{*}{ Ref } & \multirow{2}{*}{$\begin{array}{c}\text { Main } \\
\text { Characteristic }\end{array}$} & \multirow{2}{*}{$\begin{array}{l}\text { Group of } \\
\text { Method }\end{array}$} & \multirow{2}{*}{ Method } & \multicolumn{3}{|c|}{ Level of Decision } & \multicolumn{4}{|c|}{ Phase of Implementation } & \multirow{2}{*}{ MS } & \multicolumn{2}{|c|}{ Type } \\
\hline & & & & & $\mathrm{O}$ & $T$ & $S$ & $\mathrm{C}$ & $\mathbf{M}$ & Ex & A & & I & G \\
\hline 55 & {$[98]$} & en & $\mathrm{IM}$ & $\begin{array}{l}\text { MCDM } \\
\text { and AI }\end{array}$ & & & $\mathrm{x}$ & & $\mathrm{x}$ & & & & $\mathrm{x}$ & \\
\hline 56 & [99] & en & $\mathrm{AI}$ & GA & & & $\mathrm{x}$ & & & $\mathrm{x}$ & & $x$ & & $\mathrm{x}$ \\
\hline 57 & {$[100]$} & mo & $\mathrm{AI}$ & MAUT & & $\mathrm{x}$ & & & & $\mathrm{x}$ & & $x$ & & $\mathrm{x}$ \\
\hline 58 & [101] & en & MCDM & MAUT & & $\mathrm{x}$ & & & & $\mathrm{x}$ & & $x$ & & $\mathrm{x}$ \\
\hline 59 & [102] & li & MP & MP & $x$ & & & & & $\mathrm{x}$ & & & $\mathrm{x}$ & \\
\hline 60 & [103] & en & MCDM & MAUT & & & $\mathrm{x}$ & & $\mathrm{x}$ & & & $x$ & & $\mathrm{x}$ \\
\hline 61 & [104] & en & $\mathrm{IM}$ & $\begin{array}{l}\text { DEA and } \\
\text { MP }\end{array}$ & & & $\mathrm{x}$ & & $\mathrm{x}$ & & & & & $\mathrm{x}$ \\
\hline 62 & [105] & mo & MP & MP & & & $\mathrm{x}$ & & $\mathrm{x}$ & & & & $\mathrm{x}$ & \\
\hline 63 & {$[106]$} & li & MP & MP & & & $\mathrm{x}$ & & $\mathrm{x}$ & & & & $x$ & \\
\hline 64 & [107] & en & MP & MP & & & $x$ & & $x$ & & & & $x$ & \\
\hline 65 & [108] & li & AI & MAS & & $x$ & & & & $x$ & & $x$ & & $x$ \\
\hline 66 & [45] & en & $\mathrm{AI}$ & MAS & & $x$ & & & $x$ & & & $x$ & & $x$ \\
\hline 67 & [109] & en & MP & $\begin{array}{l}\text { machine } \\
\text { leaning }\end{array}$ & $\mathrm{x}$ & & & & $\mathrm{x}$ & & & & $\mathrm{x}$ & \\
\hline 68 & [110] & li & MP & MP & $x$ & & & & $x$ & & & & $x$ & \\
\hline 69 & [111] & li & MP & MP & $x$ & & & $x$ & & & & & $x$ & \\
\hline 70 & [112] & mo & MCDM & MCDM & $x$ & & & & & $x$ & & & & $x$ \\
\hline 71 & [113] & en & MCDM & MCDM & $x$ & & & & $x$ & & & & & $x$ \\
\hline 72 & [114] & pe & $\mathrm{IM}$ & $\begin{array}{l}\text { MCDM } \\
\text { and MAS }\end{array}$ & & $x$ & & & & $x$ & & $\mathrm{x}$ & & $x$ \\
\hline 73 & [115] & mo & IM & $\begin{array}{l}\text { AHP and } \\
\text { LP }\end{array}$ & $x$ & & & & $x$ & & & & & $x$ \\
\hline 74 & [49] & mo & IM & $\begin{array}{l}\text { AHP and } \\
\text { DEA }\end{array}$ & & & $x$ & & $x$ & & & & & $\mathrm{x}$ \\
\hline 75 & [116] & mo & IM & $\begin{array}{l}\text { GA and } \\
\text { Swarm }\end{array}$ & $\mathrm{x}$ & & & & $\mathrm{x}$ & & & & $x$ & \\
\hline 76 & [117] & en & AI & $\begin{array}{l}\text { Cognitive } \\
\text { theories }\end{array}$ & $x$ & & & & $x$ & & & & $\mathrm{x}$ & \\
\hline
\end{tabular}

\section{References}

1. Kapelan, Z.; Savić, D.A.; Walters, G.A. Decision-support tools for sustainable urban development. Proc. Inst. Civ. Eng. Eng. Sustain. 2005, 158, 135-142.

2. Batty, M. The New Science of Cities; The MIT Press: Cambridge, MA, USA, 2013.

3. Dupont, L.; Morel, L.; Guidat, C. Innovative public-private partnership to support Smart City: The case of "Chaire REVES". J. Strat. Manag. 2015, 8, 245-265. [CrossRef]

4. Kurniawan, F.; Wibawa, A.P.; Munir; Nugroho, S.M.S.; Hariadi, M. Makassar Smart City Operation Center Priority Optimization Using Fuzzy Multi-Criteria Decision-Making. In Proceedings of the 2017 4th International Conference on Electrical Engineering, Computer Science and Informatics (EECSI), Yogyakarta, Indonesia, 19-21 September 2017; pp. 1-5.

5. Chai, J.; Liu, J.N.K.; Ngai, E.W.T. Application of Decision-Making Techniques in Supplier Selection: A Systematic Review of Literature. Expert Syst. Appl. 2013, 40, 3872-3885. [CrossRef]

6. Eskelinen, J.; Lindy, I.; Marsh, J.; Muente-kunigami, A. Citizen-Driven Innovation: A Guidebook for City Mayors and Public Administrators; World Bank: Washington, DC, USA, 2015.

7. Lehmann, V.; Frangioni, M.; Dubé, P.; Paraponaris, D.M.S.P.C. Living Lab as knowledge system: An actual approach for managing urban service projects? J. Knowl. Manag. 2015, 19, 1087-1107. [CrossRef]

8. Giffinger, R. Smart Cities-Ranking of European Medium-Sized Cities Local; Centre of Regional Science, Vienna University of Technology: Vienna, Austria, 2007. 
9. Alawadhi, S.; Aldama-Nalda, A.; Chourabi, H.; Gil-Garcia, J.R.; Leung, S.; Mellouli, S.; Nam, T.; Pardo, T.A.; Scholl, H.J.; Walker, S. Building Understanding of Smart City Initiatives. In Proceedings of the International Conference on Electronic Government, Kristiansand, Norway, 3-6 September 2012; Volume 7443, pp. 40-53.

10. Allam, Z.; Newman, P. Redefining the Smart City: Culture, Metabolism and Governance. Smart Cities 2018, 1, 2. [CrossRef]

11. Allam, Z.; Dhunny, Z.A. On big data, artificial intelligence and smart cities. Cities 2019, 89, 80-91. [CrossRef]

12. Ruhlandt, R.W.S. The Governance of Smart Cities: A Systematic Literature Review. Cities 2018, 81, 1-23. [CrossRef]

13. Langemeyer, J.; Gómez-Baggethun, E.; Haase, D.; Scheuer, S.; Elmqvist, T. Bridging the gap between ecosystem service assessments and land-use planning through Multi-Criteria Decision Analysis (MCDA). Environ. Sci. Policy 2016, 62, 45-56. [CrossRef]

14. Sanayei, A.; Mousavi, S.F.; Yazdankhah, A. Group decision making process for supplier selection with VIKOR under fuzzy environment. Expert Syst. Appl. 2010, 37, 24-30. [CrossRef]

15. Wu, N.; Silva, E.A. Artificial Intelligence Solutions for Urban Land Dynamics: A Review. J. Plan. Lit. 2010, 24, 246-265.

16. Giang, T.T.H.; Camargo, M.; Dupont, L.; Mayer, F. A Review of Methods for Modelling Shared Decision-Making Process in a Smart City Living Lab. In Proceedings of the 2017 International Conference on Engineering, Technology and Innovation (ICE/ITMC), Funchal, Portugal, 27-29 June 2017.

17. Kabisch, N. Ecosystem service implementation and governance challenges in urban green space planning-The case of Berlin, Germany. Land Use Policy 2015, 42, 557-567. [CrossRef]

18. Pérez, A.T.E.; Camargo, M.; Rincón, P.C.N.; Marchant, M.A. Key challenges and requirements for sustainable and industrialized biorefinery supply chain design and management: A bibliographic analysis. Renew. Sustain. Energy Rev. 2017, 69, 350-359. [CrossRef]

19. Salet, W.; Bertolini, L.; Giezen, M. Complexity and Uncertainty: Problem or Asset in Decision Making of Mega Infrastructure Projects? Int. J. Urban Reg. Res. 2013, 37, 1984-2000. [CrossRef]

20. Loorbach, D. Transition Management for Sustainable Development: A Prescriptive, Complexity-Based Governance Framework. Governance 2010, 23, 161-183. [CrossRef]

21. Pereira, G.V.; Macadar, M.A.; Luciano, E.M.; Testa, M.G. Delivering Public Value through Open Government Data Initiatives in a Smart City Context. Inf. Syst. Front. 2017, 19, 213-229. [CrossRef]

22. Lacroix, J.; Dupont, L.; Guidat, C.; Hamez, G. "Smarterized” Urban Project Process with Living Lab Approach: Exploration through a Case Study. In Proceedings of the 2017 International Conference on Engineering, Technology and Innovation (ICE/ITMC), Funchal, Portugal, 27-29 June 2017.

23. Zetlaoui-Léger, J. La Programmation Architecturale et Urbaine. Émergence et Évolutions d'une Fonction. Les Cah. la Rech. Archit. Urbaine 2009, 24/25, 143-158.

24. Haase, D.; Larondelle, N.; Andersson, E.; Artmann, M.; Borgström, S.; Breuste, J.; Gómez-Baggethun, E.; Gren, Å.; Hamstead, Z.; Hansen, R.; et al. A Quantitative Review of Urban Ecosystem Service Assessments: Concepts, Models, and Implementation. Ambio 2014, 43, 413-433. [CrossRef]

25. Dupont, L.; Gholipour, V.; Morel, L.; Bignon, J.C.; Guidat, C. From Urban Concept to Urban Engineering: The Contribution of Distributed Collaborative Design to the Management of Urban Projects. J. Urban Des. 2012, 17, 255-277. [CrossRef]

26. Griffith, W.T.; Brosing, J.W. Physics of Everyday Phenomena; McGraw-Hill Higher Education: New York, NY, USA, 2001.

27. Van Eck, N.J.; Waltman, L. Software Survey: VOSviewer, a Computer Program for Bibliometric Mapping. Scientometrics 2010, 84, 523-538. [CrossRef]

28. Anagnostopoulos, T.; Zaslavsky, A.; Sosunova, I.; Fedchenkov, P.; Medvedev, A.; Ntalianis, K.; Skourlas, C.; Rybin, A.; Khoruznikov, S. A stochastic multi-agent system for Internet of Things-enabled waste management in smart cities. Waste Manag. Res. 2018, 36, 1113-1121. [CrossRef]

29. Zyrianoff, I.; Borelli, F.; Biondi, G.; Heideker, A.; Kamienski, C. Scalability of Real-Time IoT-based Applications for Smart Cities. In Proceedings of the 2018 IEEE Symposium on Computers and Communications (ISCC), Natal, Brazil, 25-28 June 2018; pp. 00688-00693.

30. Abu-Elkheir, M.; Hassanein, H.S.; Oteafy, S.M. Enhancing Emergency Response Systems through Leveraging Crowdsensing and Heterogeneous Data. In Proceedings of the 2016 International Wireless Communications and Mobile Computing Conference (IWCMC), Paphos, Cyprus, 5-9 September 2016; pp. 188-193. 
31. Sivarajah, U.; Markaki, O.; Waller, P.; Metelmann, C.; Meissner, K.; Alsaeed, A. Fostering Smart Cities through ICT Driven Policy-Making: Expected Outcomes and Impacts of DAREED Project. Int. J. Electron. Gov. Res. 2014, 10, 1-18. [CrossRef]

32. Khan, Z.; Anjum, A.; Soomro, K.; Tahir, M.A. Towards cloud based big data analytics for smart future cities. J. Cloud Comput. 2015, 4, 49. [CrossRef]

33. Fabbiani, E.; Vidal, P.; Massobrio, R.; Nesmachnow, S. Distributed Big Data Analysis for Mobility Estimation in Intelligent Transportation Systems. Comput. Vis. 2017, 697, 146-160.

34. Olszewski, R.; Turek, A.; Tan, Y.; Shi, Y. Application of the Spatial Data Mining Methodology and Gamification for the Optimisation of Solving the Transport Issues of the "Varsovian Mordor". In Proceedings of the International Conference on Data Mining and Big Data, Bali, Indonesia, 25-30 June 2016; Volume 9714, pp. 103-114.

35. Carli, R.; Dotoli, M.; Pellegrino, R. A Hierarchical Decision-Making Strategy for the Energy Management of Smart Cities. IEEE Trans. Autom. Sci. Eng. 2017, 14, 505-523. [CrossRef]

36. Ahvenniemi, H.; Huovila, A.; Pinto-Seppä, I.; Airaksinen, M. What are the differences between sustainable and smart cities? Cities 2017, 60, 234-245. [CrossRef]

37. Lugaric, L.; Krajcar, S. Transforming Cities towards Sustainable Low-Carbon Energy Systems Using Emergy. Energy Policy 2016, 98, 471-482. [CrossRef]

38. Chen, N.; Chen, Y.; You, Y.; Ling, H.; Liang, P.; Zimmermann, R. Dynamic Urban Surveillance Video Stream Processing Using Fog Computing. In Proceedings of the 2016 IEEE Second International Conference on Multimedia Big Data (BigMM), Taipei, Taiwan, 20-22 April 2016; pp. 105-112.

39. El-Sayed, H.; Sankar, S.; Prasad, M.; Puthal, D.; Gupta, A.; Mohanty, M.; Lin, C.T. Edge of Things: The Big Picture on the Integration of Edge, IoT and the Cloud in a Distributed Computing Environment. IEEE Access 2018, 6, 1706-1717. [CrossRef]

40. Mohamed, N.; Al-Jaroodi, J.; Jawhar, I. Service-Oriented Big Data Analytics for Improving Buildings Energy Management in Smart Cities. In Proceedings of the 2018 14th International Wireless Communications \& Mobile Computing Conference (IWCMC), Limassol, Cyprus, 25-29 June 2018; pp. 1243-1248.

41. Saggi, M.K.; Jain, S. A survey towards an integration of big data analytics to big insights for value-creation. Inf. Process. Manag. 2018, 54, 758-790. [CrossRef]

42. Wang, E.; Attard, S.; Everingham, Y.; Philippa, B.; Xiang, W. Smarter Irrigation Management in the Sugarcane Farming System Using Internet of Things. In Proceedings of the 40th Annual Conference of the Australian Society of Sugar Cane Technologists, Mackay, Australia, 17-20 April 2018; pp. 117-122.

43. Kraemer, M.; Ludlow, D.; Khan, Z. Domain-Specific Languages for Agile Urban Policy Modelling. In Proceedings of the 27th Conference on Modelling and Simulation, Alesund, Norway, 27-30 May 2013; pp. 673-680.

44. Khansari, N.; Silverman, B.G.; Du, Q.; Waldt, J.B.; Braham, W.W.; Lee, J.M. An Agent-Based Decision Tool to Explore Urban Climate \& Smart City Possibilities. In Proceedings of the 2017 Annual IEEE International Systems Conference (SysCon), Montreal, QC, Canada, 24-27 April 2017; pp. 1-6.

45. Kettenis, D.; Ligtenberg, A.; Beulens, A.; Bregt, A.K.; Wachowicz, M. Simulating Knowledge Sharing in Spatial Planning: An Agent-Based Approach. Environ. Plan. B Plan. Des. 2009, 36, 644-663.

46. Moghadam, S.T.; Toniolo, J.; Mutani, G.; Lombardi, P. A GIS-statistical approach for assessing built environment energy use at urban scale. Sustain. Cities Soc. 2018, 37, 70-84. [CrossRef]

47. Dowling, C.; Walsh, S.; Purcell, S. Operationalising Sustainability within Smart Cities: Towards an Online Sustainability Indicator Tool. Int. J. E Plan. Res. 2017, 6, 1-11. [CrossRef]

48. Vallejo, E.; Criado, C.; Arrizabalaga, E.; Vasallo, A. Sustainable Strategic Urban Planning: Methodology for Urban Renovation at District Level. In Proceedings of the SWC2017/SHC2017 International Conference on Solar Heating and Cooling for Buildings and Industry, Abu Dhabi, UAE, 29 October-2 November 2017; pp. $1-12$.

49. Wey, W.M. Smart Growth Principles Combined with Fuzzy AHP and DEA Approach to the Transit-Oriented Development (TOD) Planning in Urban Transportation Systems. J. Energy Technol. Policy 2013, 3, 251-258.

50. Bellini, P.; Nesi, P.; Paolucci, M.; Zaza, I. Smart City Architecture for Data Ingestion and Analytics: Processes and Solutions. In Proceedings of the 2018 IEEE Fourth International Conference on Big Data Computing Service and Applications (BigDataService), Bamberg, Germany, 26-29 March 2018; pp. 137-144. 
51. Zelentsov, L.; Mailyan, L. Creation of intelligent management systems in construction. MATEC Web Conf. 2017, 106, 8051. [CrossRef]

52. Bezerra, S.D.A.; Dos Santos, F.J.; Pinheiro, P.R.; Barbosa, F.R. Dynamic Evaluation of the Energy Efficiency of Environments in Brazilian University Classrooms Using DEA. Sustainability 2017, 9, 2373. [CrossRef]

53. Agugiaro, G. enabling "energy-awareness" in the semantic 3d city model of vienna. ISPRS Ann. Photogramm. Remote Sens. Spat. Inf. Sci. 2016, IV-4/W1, 81-88. [CrossRef]

54. Bhattacharya, D.; Painho, M. Smart cities intelligence system (smacisys) integrating sensor web with spatial data infrastructures (sensdi). ISPRS Ann. Photogramm. Remote Sens. Spat. Inf. Sci. 2017, IV-4/W3, 21-28. [CrossRef]

55. Terribile, F.; Agrillo, A.; Bonfante, A.; Buscemi, G.; Colandrea, M.; D'antonio, A.; De Mascellis, R.; De Michele, C.; Langella, G.; Manna, P.; et al. A Web-based spatial decision supporting system for land management and soil conservation. Solid Earth 2015, 6, 903-928. [CrossRef]

56. Pardo-Bosch, F.; Aguado, A.; Pino, M. Holistic Model to Analyze and Prioritize Urban Sustainable Buildings for Public Services. Sustain. Cities Soc. 2019, 44, 227-236.

57. Eräranta, S.; Staffans, A. From Situation Awareness to Smart City Planning and Decision Making. In Proceedings of the International Conference on Computers in Urban Planning and Urban Management, Cambridge, MA, USA, 7-10 July 2015.

58. Liu, Y.; Wang, H.; Tzeng, G.H. From Measure to Guidance: Galactic Model and Sustainable Development Planning toward the Best Smart City. J. Urban Plan. Dev. 2018, 144, 04018035. [CrossRef]

59. Ju, J.; Liu, L.; Feng, Y. Citizen-centered big data analysis-driven governance intelligence framework for smart cities. Telecommun. Policy 2018, 42, 881-896. [CrossRef]

60. Mouchili, M.N.; Aljawarneh, S.; Tchouati, W. Smart City Data Analysis. In Proceedings of the First International Conference on Data Science, E-learning and Information Systems DATA '18, Madrid, Spain, 1-2 October 2018; p. 33.

61. Fadda, E.; Gobbato, L.; Perboli, G.; Rosano, M.; Tadei, R. Waste Collection in Urban Areas: A Case Study. Interfaces 2018, 48, 307-322. [CrossRef]

62. Stefanic, P.; Kimovski, D.; Suciu, G.; Stankovski, V. Non-Functional Requirements Optimisation for Multi-Tier Cloud Applications: An Early Warning System Case Study. In Proceedings of the 2017 IEEE SmartWorld, Ubiquitous Intelligence \& Computing, Advanced \& Trusted Computed, Scalable Computing \& Communications, Cloud \& Big Data Computing, Internet of People and Smart City Innovation (SmartWorld/SCALCOM/UIC/ATC/CBDCom/IOP/SCI), San Francisco, CA, USA, 4-8 August 2017; pp. 1-8.

63. Pereira, G.V.; Eibl, G.; Stylianou, C.; Martínez, G.; Neophytou, H.; Parycek, P. The Role of Smart Technologies to Support Citizen Engagement and Decision Making. Int. J. Electron. Gov. Res. 2019, 14, 1-17. [CrossRef]

64. Abastante, F.; Lami, I.M.; Lombardi, P. An Integrated Participative Spatial Decision Support System for Smart Energy Urban Scenarios: A Financial and Economic Approach. Buildings 2017, 7, 103. [CrossRef]

65. Abdel-Basset, M.; Mohamed, M. The role of single valued neutrosophic sets and rough sets in smart city: Imperfect and incomplete information systems. Measurement 2018, 124, 47-55. [CrossRef]

66. Mihăiţă, A.S.; Dupont, L.; Camargo, M. Multi-objective traffic signal optimization using 3D mesoscopic simulation and evolutionary algorithms. Simul. Model. Pract. Theory 2018, 86, 120-138. [CrossRef]

67. Giacobbe, M.; Di Pietro, R.; Minnolo, A.L.; Puliafito, A. Evaluating Information Quality in Delivering IoT-as-a-Service. In Proceedings of the 2018 IEEE International Conference on Smart Computing (SMARTCOMP), Taormina, Italy, 18-20 June 2018; pp. 405-410.

68. Gheibi, M.; Karrabi, M.; Mohammadi, A.; Dadvar, A. Controlling air pollution in a city: A perspective from SOAR-PESTLE analysis. Integr. Environ. Assess. Manag. 2018, 14, 480-488. [CrossRef]

69. Abbasi, M.H.; Majidi, B.; Manzuri, M.T. Deep Cross Altitude Visual Interpretation for Service Robotic Agents in Smart City. In Proceedings of the 2018 6th Iranian Joint Congress on Fuzzy and Intelligent Systems (CFIS), Kerman, Iran, 28 February-2 March 2018; pp. 79-82.

70. Kinawy, S.; El-Diraby, T.; Konomi, H. Customizing information delivery to project stakeholders in the smart city. Sustain. Cities Soc. 2018, 38, 286-300. [CrossRef]

71. D'Aniello, G.; Gaeta, M.; Orciuoli, F. An approach based on semantic stream reasoning to support decision processes in smart cities. Telemat. Inform. 2018, 35, 68-81. [CrossRef]

72. Hou, W.; Ning, Z.; Guo, L. Green Survivable Collaborative Edge Computing in Smart Cities. IEEE Trans. Ind. Inform. 2018, 14, 1594-1605. [CrossRef] 
73. Iqbal, M.M.; Mehmood, M.T.; Jabbar, S.; Khalid, S.; Ahmad, A.; Jeon, G. An enhanced framework for multimedia data: Green transmission and portrayal for smart traffic system. Comput. Electr. Eng. 2018, 67, 291-308. [CrossRef]

74. Manqele, L.; Adeogun, R.; Dlodlo, M.; Coetzee, L. Multi-Objective Decision-Making Framework for Effective Waste Collection in Smart Cities. In Proceedings of the 2017 Global Wireless Summit (GWS), Cape Town, South Africa, 15-18 October 2017; pp. 155-159.

75. Rad, T.G.; Sadeghi-Niaraki, A.; Abbasi, A.; Choi, S.-M. A methodological framework for assessment of ubiquitous cities using ANP and DEMATEL methods. Sustain. Cities Soc. 2018, 37, 608-618.

76. Mosannenzadeh, F.; Di Nucci, M.R.; Vettorato, D. Identifying and prioritizing barriers to implementation of smart energy city projects in Europe: An empirical approach. Energy Policy 2017, 105, 191-201. [CrossRef]

77. Rahman, A.; Jin, J.; Cricenti, A.; Rahman, A.; Panda, M. Motion and Connectivity Aware Offloading in Cloud Robotics via Genetic Algorithm. In Proceedings of the 2017 IEEE Global Communications Conference, Singapore, 4-8 December 2017; pp. 1-6.

78. Fedyanin, D.; Vershinin, Y. On Distributed Reflexive Complex Mechanisms of Decision-making in a Transportation System of a Smart city. Int. J. Eng. Technol. 2018, 7, 164-167. [CrossRef]

79. El Hendy, M.; Miniaoui, S.; Fakhry, H. Towards Strategic Information \& Communication Technology (ICT) Framework for Smart Cities Decision-Makers. In Proceedings of the 2015 2nd Asia-Pacific World Congress on Computer Science and Engineering (APWC on CSE), Nadi, Fiji, 2-4 December 2015; pp. 1-7.

80. Yang, Q.; Li, G.; Cai, T.; Wang, Q. Underground Intelligent Logistic System Integrated with Internet of Things. Agreem. Technol. 2018, 11226, 298-302.

81. Ruiz, X.; Calvet, L.; Ferrarons, J.; Juan, A. SmartMonkey: A Web Browser Tool for Solving Combinatorial Optimization Problems in Real Time; Springer Science and Business Media LLC: Berlin, Germany, 2018; pp. 74-86.

82. Eswaran, S.P.; Sripurushottama, S.; Jain, M. Multi Criteria Decision Making (MCDM) based Spectrum Moderator for Fog-Assisted Internet of Things. Procedia Comput. Sci. 2018, 134, 399-406. [CrossRef]

83. Oswald-Beiler, M.R.O.; Phillips, B. Prioritizing Pedestrian Corridors Using Walkability Performance Metrics and Decision Analysis. J. Urban Plan. Dev. 2016, 142, 4015009. [CrossRef]

84. Rondini, A.; Lagorio, A.; Pinto, R.; Pezzotta, G. A multi-criteria decision making approach for prioritising product-service systems implementation in smart cities. Int. J. Manag. Decis. Mak. 2018, 17, 415.

85. Wang, S.; Wu, J.; Zhang, Y. Consumer preference-enabled intelligent energy management for smart cities using game theoretic social tie. Int. J. Distrib. Sens. Netw. 2018, 14, 155014771877323. [CrossRef]

86. De Maio, C.; Fenza, G.; Loia, V.; Orciuoli, F. Distributed online Temporal Fuzzy Concept Analysis for stream processing in smart cities. J. Parallel Distrib. Comput. 2017, 110, 31-41. [CrossRef]

87. Abberley, L.; Gould, N.; Crockett, K.; Cheng, J. Modelling Road Congestion Using Ontologies for big Data Analytics in Smart Cities. In Proceedings of the 2017 International Smart Cities Conference (ISC2), Wuxi, China, 14-17 September 2017; pp. 1-6.

88. Digiesi, S.; Mossa, G.; Mummolo, G.; Verriello, R. A Carbon Footprint Calculator for the Municipal Waste Collection System of Bari. In Proceedings of the XX Summer School "Francesco Turco" —Industrial Systems Engineering, Naples, Italy, 16-18 September 2015; pp. 165-172.

89. Saaty, T.L.; De Paola, P. Rethinking Design and Urban Planning for the Cities of the Future. Buildings 2017, 7, 76. [CrossRef]

90. Orłowski, C. Rule-Based Model for Selecting Integration Technologies for Smart Cities Systems. Cybern. Syst. 2014, 45, 136-145. [CrossRef]

91. Sarkar, M.; Banerjee, S.; Badr, Y.; Sangaiah, A.K. Configuring a Trusted Cloud Service Model for Smart City Exploration Using Hybrid Intelligence. Int. J. Ambient. Comput. Intell. 2017, 8, 1-21. [CrossRef]

92. D'Asaro, F.A.; Di Gangi, M.A.; Perticone, V.; Tabacchi, M.E. Computational Intelligence and Citizen Communication in the Smart City. Inform. Spektrum 2017, 40, 25-34. [CrossRef]

93. Latorre-Biel, J.-I.; Faulin, J.; Jiménez, E.; Juan, A.A.; Alba, E.; Chicano, F.; Luque, G. Simulation Model of Traffic in Smart Cities for Decision-Making Support: Case Study in Tudela (Navarre, Spain). In Proceedings of the International Conference on Smart Cities, Malaga, Spain, 14-16 June 2017; Volume 10268, pp. 144-153.

94. Mokoena, B.T.; Musakwa, W.; Moyo, T. Developing the Well-Located Land Index to Establish Smart Human Settlements for the Ekurhuleni Municipality, South Africa. Lect. Notes Geoinf. Cartogr. 2017, 6, 95-112.

95. Lazaroiu, G.C.; Roscia, M. Definition methodology for the smart cities model. Energy 2012, 47, $326-332$. [CrossRef] 
96. Anthopoulos, L.G.; Gerogiannis, V.C.; Fitsilis, P. Supporting the Solution Selection for a Digital City with a Fuzzy-Based Approach. In Proceedings of the KMIS 2011-International Conference on Knowledge Management and Information Sharing, Paris, France, 26-29 October 2011; pp. 355-358.

97. Kulju, M.; Oksman, V. Developing online illustrative and participatory tools for urban planning: Towards open innovation and co-production through citizen engagement. Int. J. Serv. Technol. Manag. 2017, 23, 445. [CrossRef]

98. Maktav, D.; Jürgens, C.; Siegmund, A.; Sunar, F.; Esbah, H.; Kalkan, K.; Uysal, C.; Mercan, O.Y.; Akar, I.; Thunig, H.; et al. Multi-Criteria Spatial Decision Support System for Valuation of Open Spaces for urban Planning. In Proceedings of the 5th International Conference on Recent Advances in Space Technologies-RAST2011, Istanbal, Turkey, 9-11 June 2011; pp. 160-163.

99. Raikov, A.N. Strategic Planning of Science City Socioeconomic Development. In Digital Transformation and Global Society. DTGS 2017; Alexandrov, D., Boukhanovsky, A., Chugunov, A., Kabanov, Y., Koltsova, O., Eds.; Communications in Computer and Information Science, vol 745; Springer: Cham, Switzerland, 2017.

100. Chowdhary, N.; Kaur, P.D. Increasing Route Availability in Internet of Vehicles Using Ant Colony Optimization. Comput. Vis. 2017, 712, 318-331.

101. Rall, E.L.; Haase, D. Creative intervention in a dynamic city: A sustainability assessment of an interim use strategy for brownfields in Leipzig, Germany. Landsc. Urban Plan. 2011, 100, 189-201. [CrossRef]

102. Moreno, V.; Ferrer, J.A.; Díaz, J.A.; Bravo, D.; Chang, V. A Data-Driven Methodology for Heating Optimization in Smart Buildings. In Proceedings of the 2nd International Conference on Internet of Things, Big Data and Security, Porto, Portugal, 24-26 April 2017; pp. 19-29.

103. Hermans, C.; Erickson, J.; Noordewier, T.; Sheldon, A.; Kline, M. Collaborative environmental planning in river management: An application of multicriteria decision analysis in the White River Watershed in Vermont. J. Environ. Manag. 2007, 84, 534-546. [CrossRef]

104. Dos Santos, M.J.P.L. Smart Cities and Urban Areas-Aquaponics as Innovative Urban Agriculture. Urban For. Urban Green. 2016, 20, 402-406. [CrossRef]

105. Mourshed, M.; Bucchiarone, A.; Khandokar, F. SMART: A Process-Oriented Methodology for Resilient Smart Cities. In Proceedings of the 2016 IEEE International Smart Cities Conference (ISC2), Trento, Italy, 12-15 September 2016; pp. 1-6.

106. Orłowski, C.; Ziółkowski, A.; Orlowski, A.; Kaplanski, P.; Sitek, T.; Pokrzywnicki, W. KPIs as a Method of Implementing Decision-Making Processes in the Management of Smart Cities. In Transactions on Computational Collective Intelligence XXV; Nguyen, N., Kowalczyk, R., Orłowski, C., Ziółkowski, A., Eds.; Lecture Notes in Computer Science, vol. 9990; Springer: Berlin/Heidelberg, Germany, 2016.

107. Carli, R.; Dotoli, M.; Andria, G.; Lanzolla, A.M.L. Bi-Level Programming for the Strategic Energy Management of a Smart City. In Proceedings of the 2016 IEEE Workshop on Environmental, Energy, and Structural Monitoring Systems (EESMS), Bari, Italy, 13-14 June 2016; pp. 1-6.

108. Fahad, M.; Boissier, O.; Maret, P.; Moalla, N.; Gravier, C. Smart places: Multi-agent based smart mobile virtual community management system. Appl. Intell. 2014, 41, 1024-1042. [CrossRef]

109. Ghosh, D.; Ae Chun, S.; Shafiq, B.; Adam, N.R. Big Data-Based Smart City Platform: Real-Time Crime Analysis. In Proceedings of the 17th International Digital Government Research Conference on Digital Government Research-dg.o '16, Shanghai, China, 8-10 June 2016; pp. 58-66.

110. Rolim, O.C.; Rossetto, A.G.D.M.; Leithardt, V.R.; Borges, G.A.; Geyer, C.F.; Dos Santos, T.F.; Souza, A.M. A Novel Engine to Underlie the Data Transmission of Social Urban Sensing Applications. In Proceedings of the 2015 IEEE Symposium on Computers and Communication (ISCC), Larnaca, Cyprus, 6-9 July 2015; pp. 677-682.

111. Kosmides, P.; Adamopoulou, E.; Demestichas, K.; Theologou, M.; Anagnostou, M.; Rouskas, A. Socially Aware Heterogeneous Wireless Networks. Sensors 2015, 15, 13705-13724. [CrossRef]

112. Foucault, J.P.; Moulier-Boutang, Y. Towards Economic and Social "Sensors": Condition and Model of Governance and Decision-Making for an Organologocal Smart City. In Proceedings of the 2015 International Conference on Smart and Sustainable City and Big Data, Shanghai, China, 26-27 July 2015; pp. 106-112.

113. Papastamatiou, I.; Doukas, H.; Psarras, J. An Information Management Software for Assessing Smart Energy Systems Exploiting Cities' Multidisciplinary Data. IISA. In Proceedings of the 5th International Conference on Information, Intelligence, Systems and Applications, Chania, Greece, 7-9 July 2014; pp. 285-290. 
114. Palomares, I.; Martinez, L. A Semi-Supervised Multi-Agent System Model to Support Consensus Reaching Processes. IEEE Trans. Fuzzy Syst. 2013, 22, 762-777.

115. Meza, J.L.C.; Yildirim, M.B.; Masud, A.S.M. A Model for the Multiperiod Multiobjective Power Generation Expansion Problem. IEEE Trans. Power Syst. 2007, 22, 871-878.

116. Amini, M.H.; Moghaddam, M.P.; Karabasoglu, O. Simultaneous allocation of electric vehicles' parking lots and distributed renewable resources in smart power distribution networks. Sustain. Cities Soc. 2017, 28, 332-342.

117. Khansari, N.; Mostashari, A.; Mansouri, M. Conceptual Modeling of the Impact of Smart Cities on Household Energy Consumption. Procedia Comput. Sci. 2014, 28, 81-86.

(C) 2019 by the authors. Licensee MDPI, Basel, Switzerland. This article is an open access article distributed under the terms and conditions of the Creative Commons Attribution (CC BY) license (http://creativecommons.org/licenses/by/4.0/). 